Dept. of Animal production

Faculty of Agric. Assiut Univ.

Head of Dept.; Prof. Dr. M.N. Makled.

\title{
CHANGES IN CERTAIN BLOOD AND MILK CONSTITUENTS DURING THE FIRST 5 WEEKS POST-LAMBING IN COARSE-WOOL EWES OF UPPER EGYPT
}

(With 2 Tables \& 4 Figures)

\author{
By
}

H.A. DAGHASH*; M.M. SHETAEWI* and N.M. SAAD**

(Received at 13/5/1993)

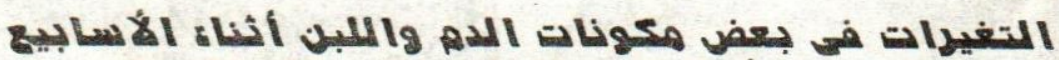

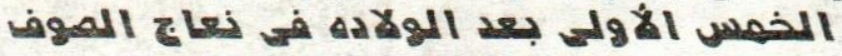

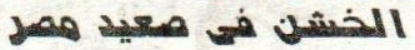

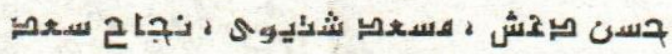

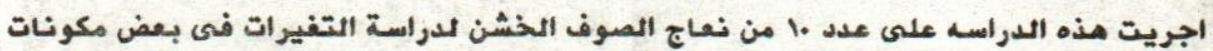

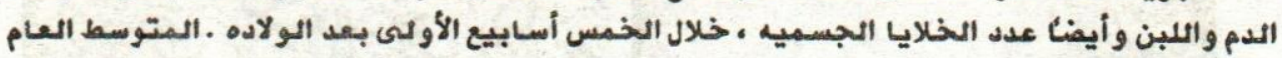

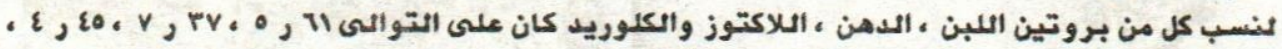

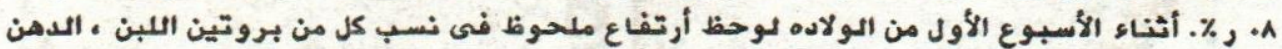

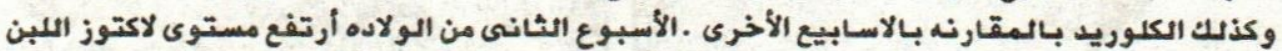

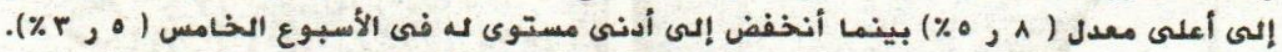

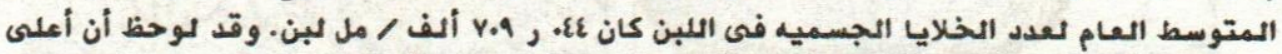

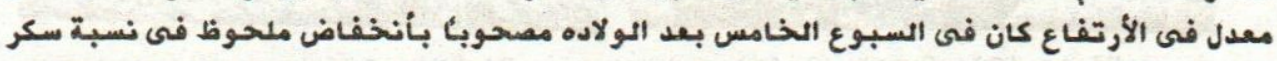

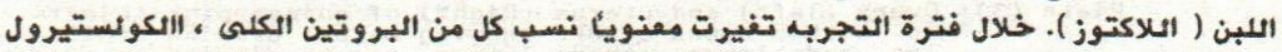

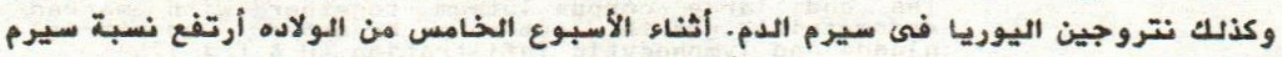

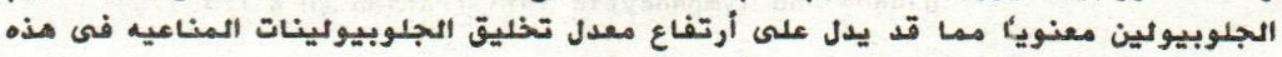

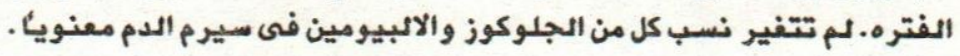

*: Dep. of Animal Production, Fac. of Agriculture **: Dept. of Food Control, Fac. of Vet. Med. Assiut Univ., Assiut, Egypt. 


\section{SUMMARY}

Ten coarse-wool Saidi ewes of Upper Egypt were utilized to study changes in certain blood and milk constituents and somatic cell counts during the first 5 weeks post-lambing. The overall means of milk protein, fat, lactose, chloride percentages were $5.61,7.37,4.45$ and 0.08 respectively. Milk protein, fat and chloride percentages were higher during the 1st wk of lactation compared with other weeks. A significant positive correlation ( $r=+$ $0.5, \mathrm{P}<0.01$ ) was obtained between milk protein and fat percentages. Lactose percentage reached the highest level during the 2nd wk $(5.8 \%)$ and the lowest level during the 5 th wk $(3.5 \%, P<0.05)$. The overall mean of somatic cell counts was 709.044 $\mathrm{X} 10^{3} \mathrm{celi} / \mathrm{ml}$. The high somatic cell count was observed at wk 5 of lactation and coincided with the lowest level of actose. Significant changes $(P<0.05)^{\circ}$ occurred in serum total protein, cholesternl, and urea $\mathrm{V}$ through lactation weeks. Serum globulin was highest $(P<0.07)$ during the 5 th wk $(4.18 \mathrm{~g} / \mathrm{dl})$ which ildicate increased rate of immunoglobulin biosynthisis. Changes in serum glucose and albumin were not significant.

(Keywords: Milk, blood, la?tation, sheep, ewe).

\section{INTRODUCTION}

Most studies on postpartum changes in milk composition and somatic cell count and the corresponding changes in serum metabolites have been confined to cattle. No complete data exist for the Egyptian ewes. The objective of this study was to determine postpartum changes in milk composition and somatic cell counts in retation to changes in selected serum constituents.

\section{MATERIAL and METHODS}

This trail was carried out in the Experimental Farm of the Department of Animal Production. Ten coarse-wool Saidi ewes of Upper Egypt were used after lambing. All animals received 1.5 $\mathrm{kg}$ daily of a pelleted concentrate diet prepared commercially and consisted of wheat bran $(40.5 \%)$, cotton seed meal $(10 \%)$,

Assiut Vet. Med. J. Vol. 29, No. 58, 1993. 


\section{H.A. DAGHASH, et al}

soybean meal ( $2 \%$ ), molasses $(9 \%)$, corn $(12 \%)$, rice hulls $(7.5 \%)$, flax straw (14\%), limestone $(3.5 \%)$ and mineralized salt (1.5\%) on dry matter (D.M.) basis. Milk and blood samples were obtained from ewes at 0900 at wk $1,2,3$ and 5 post-lambing. Blood samples were collected by jugular venipuncture using a clean dry plastic syringe and then transferred to centrifuge tubes and allowed to clot at room temperature. Serum was then separated by centrifugation at $3000 \mathrm{rpm}$ from $15 \mathrm{~min}$. Serum was subsequently decanted into glass vials and stored at $-20 \mathrm{C}$ until it was analyzed. Serum glucose, cholesterol and albumin were analyzed using kits supplied by BioMeriex, France; serum total protein was analyzed using a kit supplied by BioAnalytics, Florida, U.S.A. and serum globulin was claculated mathematically by difference. Serum urea $\mathrm{N}$ was estimated using assay kits of Diamond Diagnostic, Egypt. Milk samples were immediately used to determine percentages of total milk protein by Kjeldahl's methods (OGG et al., 1948), fat by Gerber method (APHA, 1978), lactose by Benedict method (HARVEY and HILL, 1967), chloride (LING, 1963). Somatic cell counts (Scc) were determined as described by ROUSHDY et al. (977). Data were analyzed using general linear model (GLM) procedure described in SAS (1987) for personal computers. Serum and milk constituents and somatic cell counts were analyzed by splitplot analysis of variance for repeated measures (GILL and HAFS, 1971).

\section{Milk constituents:}

\section{RESULTS}

Changes of milk total protein, fat and chloride percentages during the first 5 wk of lactation are presented in Table 1 and Figure 1 . Milk total protein was relatively high during the 1st wk, then decreased by about $25 \%$ during the 2nd wk and slightly increased thereafter. Milk fat percentage also decreased by about $8 \%$ during the 2 nd wk compared with the 1 st wk and reached the lowest level at the sth wk $(6.57 \%, \mathrm{P}<0.05)$. Chloride percentage was relatively higher during the 1st wk compared with subsequent weeks. Significant changes $(P<0.05)$ occurred in lactose percentages through lactation weeks (Table 1 and Fig. 1). Lactose \% peaked at the 2 ndwk, then continued to decrease to reach the lowest level at the 5 th wh of lactation. Somatic cell counts (Table 1 and Fig. 2) remained almost constant during the 1st and 2nd wk of lactation, then increased by about $21 \%$ during the 3 rd $w k$ and about $72 \% \quad(P<0.05)$ during the 5 th wk compared with the 1 st one.

Assiut Vet. Med. J. Vol. 29, No. 58, 1993. 


\section{CHANGES BLOOD, MILK \& POST-LAMBING}

Blood costituents: Changes in serum glucose concentrations through weeks of lactation were not significant ( Table 2 and Fig. 3 ). However, serum glucose level tended to increase consistently through weeks of lactation. On the other hand, serum cholesterol level remained relatively constant during the first $15 \mathrm{~d}$ of lactation, then decreased by about $30 \%$ at the 3 rd wk, to increase again to reach the highest level at the 5 th wk $(71.8 \mathrm{mg} / \mathrm{dl}, \quad P<0.07)$. Significant changes $(P<0.05)$ in serum total protein occurred during lactation weeks (Table 2 and Fig. 4). The lowest value was recorded at the $3 \mathrm{rd}$ wk $(5.77 \mathrm{~g} / \mathrm{dl})$ and highest value was recorded at the 5 th wk $(8.32 \mathrm{~g} / \mathrm{dl})$. This trend was almost noticed for serum albumin and globulin levels (Table 2 and Fig. 4). Substantial changes $(P<0.05)$ occurred in serum urea $\mathrm{N}$ concentrations through lactation weeks ( Table 2 and Fig. 3 ). In contrast to serum cholesterol, total protein and globulin concentrations in which the lowest levels were recorded at $3 r d$ wk, serum urea $N$ level was highest at the 3 rd week.

\section{DISCUSSION}

Means of milk constituents in the present study (Table 1) are within normal range reported by BREMEL (1982) and JENNESS (1985) in foreign breeds of sheep. But somatic cell counts in milk of Saidi ewes were above the normal values of 50,000 to 200,000 cells/ml milk of non-infacted cows. The higher percentages of milk protein and fat during the 1 st wk of lactation compared with subsequent weeks were anticipated because of the increase in water secretion (associated with the increase in milk production) after the 1 st wk of lactation. A significant positive correlation was obtained between milk protein and fat percentage $(r=+0.50, P<0.01)$. The increase in milk lactose percentage during the 2 nd wk is unclear, but the decrease during the 5 th wk could be due to increase somatic cell count during the 5 th wk of lactation. RENNER (1922),, GIESECKE and VAN DER HEEVER (1974) and GLABOWNA et al. (1989) reported that reduced lactose values were related to udder infection or mastitis in cattle. Somatic cell counts are related to both milk yield and milk flow rate as well as intramammary pressure and accumulated end products in the cells (HUCK, 1977; GUIDRY, 1985; DAGHASH, 1989). In the present study, the increase in somatic cell counts at wk 3 and obviously at wk $5(\mathrm{P}<0.05)$ of lactation, might be the result of increased intramammary pressure and accumulated end products in the cells (HUCK, 1977; GUIDRY, 1985; WATERMAN and GOREWIT,

Assiut Vet. Med. J. Vo1. 29, No. 58, 1993. 


\section{H. A. DAGHASH, et al}

1980). Means of serum constituents in the present study fall within normal range reported by HALLFORD and GALYEAN (1982) and SHETAEWI and ROSS (1991) in fine wool sheep. Although changes in serum glucose concentrations through weeks of lactation were not significant (Table 2), the highest level for serum glucose (wk 5 ) coincided with the lowest level of milk lactose ( Table 1 ). This finding might be due to decreased rate of glucose uptake by mammary gland cells for biosynthesis of lactose (COLLIER, 1985). The sharp decrease in serum cholesterol, together with serum total protein and globulin during the 3rd wk of lactation (Table 2 and Fig. 3 \& 4) could be due to decreased availability of nutrients, increased rate of degradation. The increase in serum urea $\mathrm{N}$ concentration during the 3rd wk might indicated that degradation of protein was higher during that period. The reverse was true during the 5 th wk (Table 2 and Fig. 3). Serum globulin (Table 2 and Fig. 4) reached the highest level at wk 5 of lactation $(P<0.07)$, and was even higher than serum albumin $(4.18 \mathrm{vs} 3.52, \mathrm{~g} / \mathrm{dl}$, respectively). Increased rate of immunoglobulin biosynthesis during that period might explain this observation.

\section{REFERENCES}

Apha. (1978): Standard Method for the Examination of Dairy Products. 14th Ed. New York American Public Health Association Inc.

Breme1, R. (1982): Lactation. (1st Ed.). Wisconsin State Univ. Press. Wisconsin, Madison.

Collier, R.J. (1985): Nutritional, metabolic and enviromental aspects of lactation. In : B.L.Larson (Ed). Lactation. pp 80-128 (1st Ed). Iowa State Univ. Press, Ames.

Daghash, H.A. (1989): Diurnal Rhythm of Milk Secretion in Cattle. Ph. D. Thesis. Assiut Univ., Assiut, Egypt.

Giesecke, W.H. and Van der Heever, L.W. (1974): The diagnosis of bovine mastitis with pareicular reference to subchemical mastitis. A critical review of relevant literature. Onderstepoort. J. Vet. Res. 41. p. 169.

Gil1, J.L. and Hafs,H.D. (1971): Analysis of repeated measurements of animals. J. Anim. Sci. 33: 331-336.

Glabowna, M.; Sender, G.; Lukaszwewicz, M. and Bsssalik -Chabielska, L. (1989): the influence of selected factors upon the lactose level in milk as mastitis indicator. Milchwissenschaft. 43: 22-24.

Assiut Vet, Med. J. Vol. 29, No. 58, 1993. 
Guidry, A.J. (1985): Mastitis and the immune system of the mammary gland. In: B. L. Larson (Ed.) Lactation. pp 229-262 (1st Ed. ). Iowa State Univ. Press, Ames.

Hallford, D.M. and Galyean, M.L. (1982): Serum profiles in fine-wool sheep. Bovine Practice 3 (4): 26-32.

Harvey, W. and Hill, H. (1967): Milk production and control. (1st Ed. ). Lewis and Co. London.

Huck. P. (1977): Auswirkungen der milkfrequenz auf entwicklung und activitaete des paranchymes in milchdrusen von erstalaktierenden. DSB, Kuehen. Diss. Univ. Hohenheim, Germany.

Jenness, R. (1985): Biochemical and nutritional aspects of milk and colostrum. In: B. L. Larson (Ed.). Lactation. pp 164 197 (1st Ed.). Iowa State Univ. Press, Ames.

Ling, E. (1963): A Textbook of Dairy Chemistry. 3rd Ed. Champan and $\mathrm{Ha} 11$ LTD. London.

Ogg, G.L.; Brand, R.W. and Whillits, C.O. (1948): Micro and semimicro determination of $\mathrm{N}$ in heterocyclin $\mathrm{N}$ ring compounds by a kjeldahl method. J. Assoc. of Agr. Chem. 31. p. 663.

Renner, E. (1922): Der lactose ghalt der milch als indikator fur eutererkrankungen. Archiv fur lebebsmiltelhygiene. 23: 25-29.

Roushdy, A. ; Nasr, SS. and Moursy, A.W. (1977): Practical food hygiene. p. 45: (1 $\underline{\text { st }}$ Ed.) part I.

Sas (1987): SAS/STAT Guie for personal computers (Ver. 6). SAS Ins. Inc. Cary, N. C.

Shetaewi, M.M. and Ross, T.T. (1991): Effects of concentrate suppllementation and lasalocid on serum chemistry and hormone profiles in Rambouillet ewes. Small Rumin. Res. 4: 365377.

Waterman, D.F. and Gorewit, R.C. (1980): The effect of three times a day milking on milk yield, milk components and udder health. J. Dairy Sci. 63: p. 119.

Assiut Vet. Med. J. Vol. 29, No. 58, 1993. 


\section{H.A. DAGHASH, et al}

Table 1. Milk proteln, fat, lactose, and somatic cell concentrations in Saidi ewes through weoks of lactationa

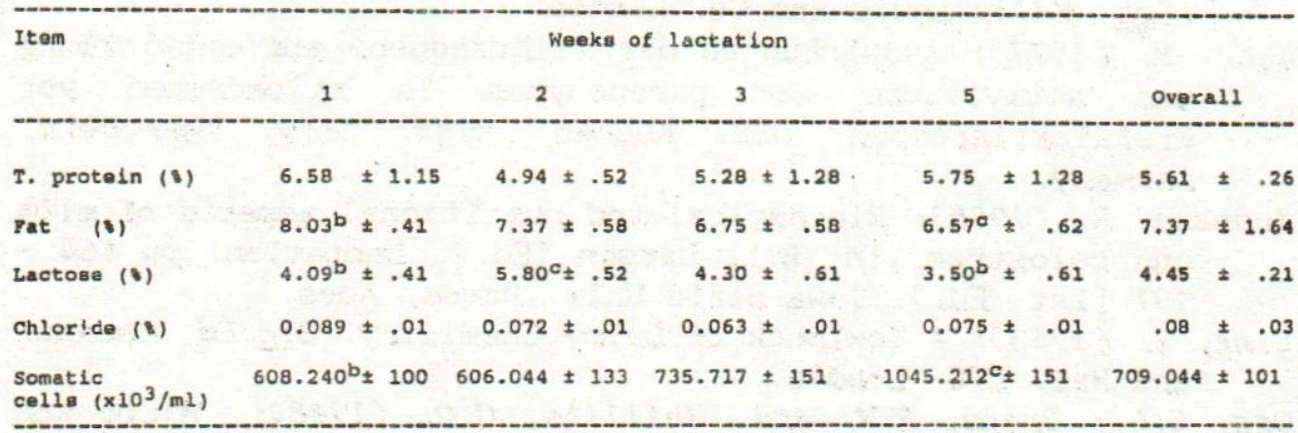

avalues are least-squares means \pm standard errora.

b. CMeang in the same row not having a common superseript differ (P<.05).

Table 2. Concentrations of some serum constituents in Saidi ewes through weeks of lactation

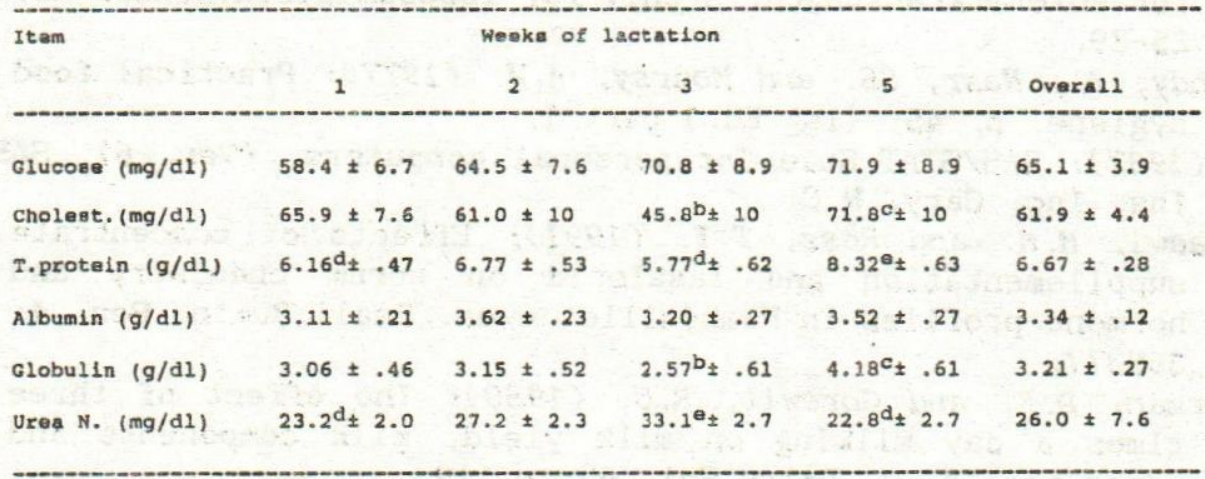

avalues are least-squares means \pm atandard errors.

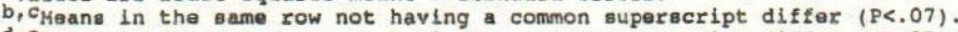

d, Means in the same row not having a common auperacript differ (P<.05).

Assiut Vet. Med. J. Vol. 29, No. 58, 1993. 
Figure 1. Milk protein, fat, and chloride

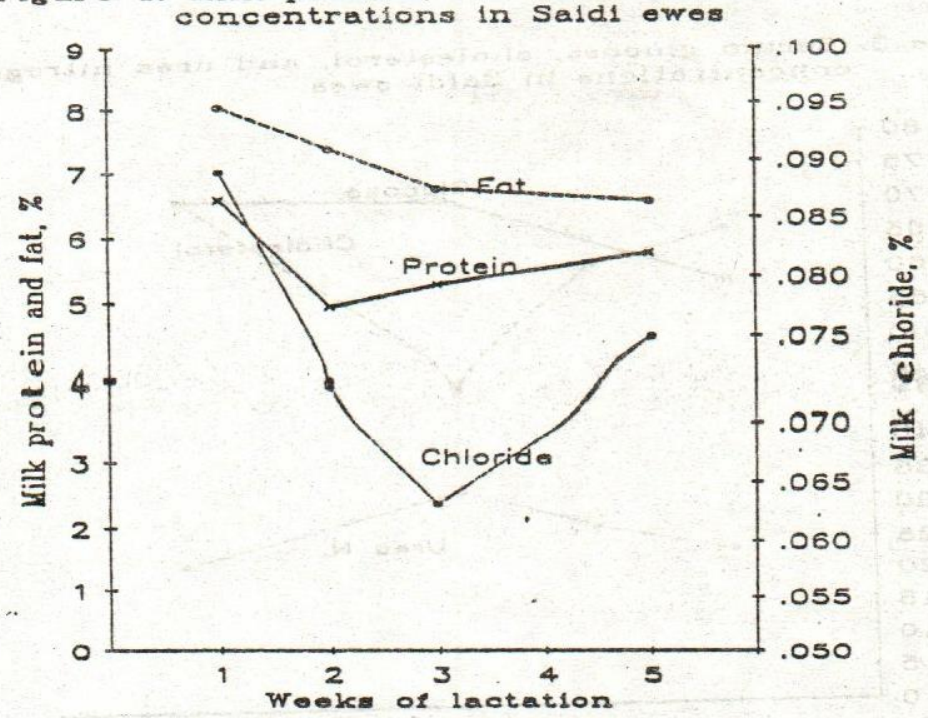

Figure 2. Milk lactose and somatic cell concentrations in Saldi ewes

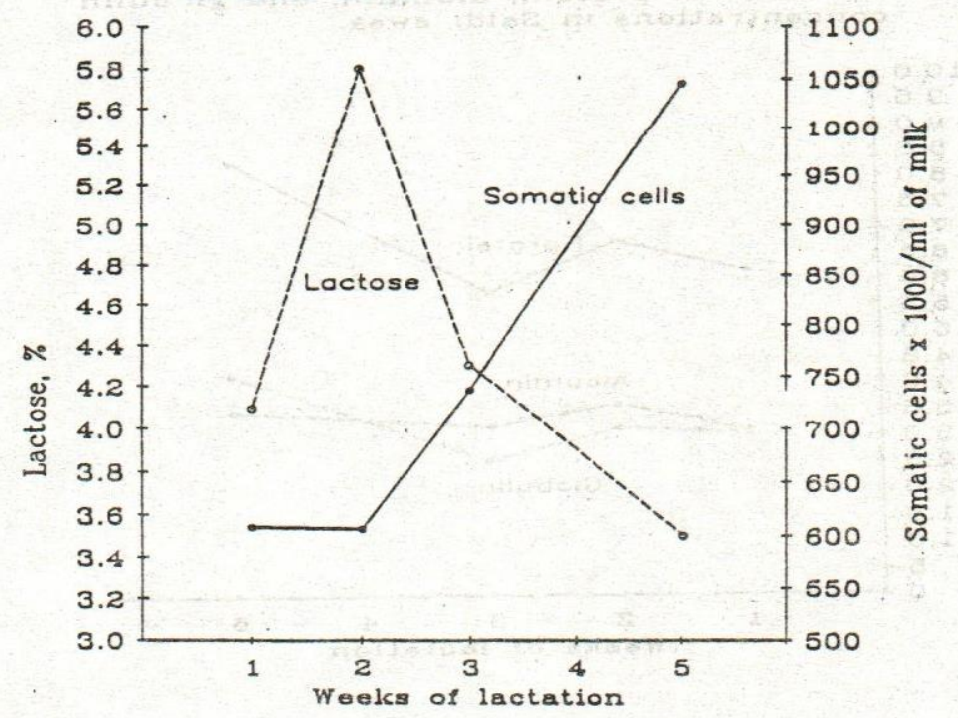

Assiut Vet. Med. J. Vol. 29, No. 58, 1993. 


\section{H. A. DAGHASH, et al}

Figura 3. Serum glucose, cholesterol, and uraa nitrogen
concentrations in Saldi owos.

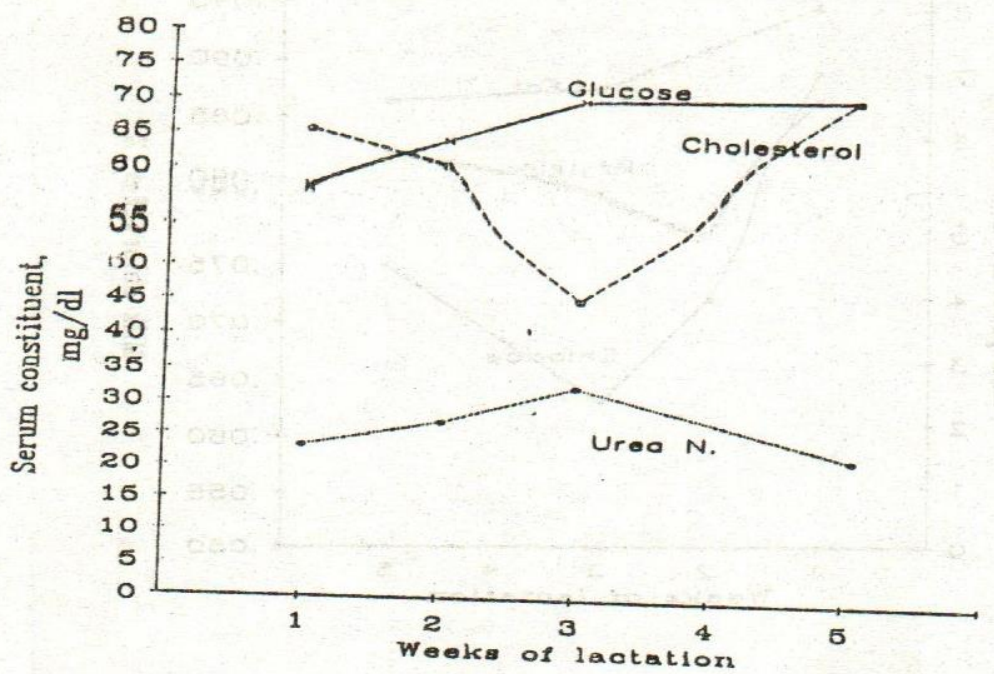

Figure 4. Serum total protein, albumin, and globulin concentrations in Saldi owos.

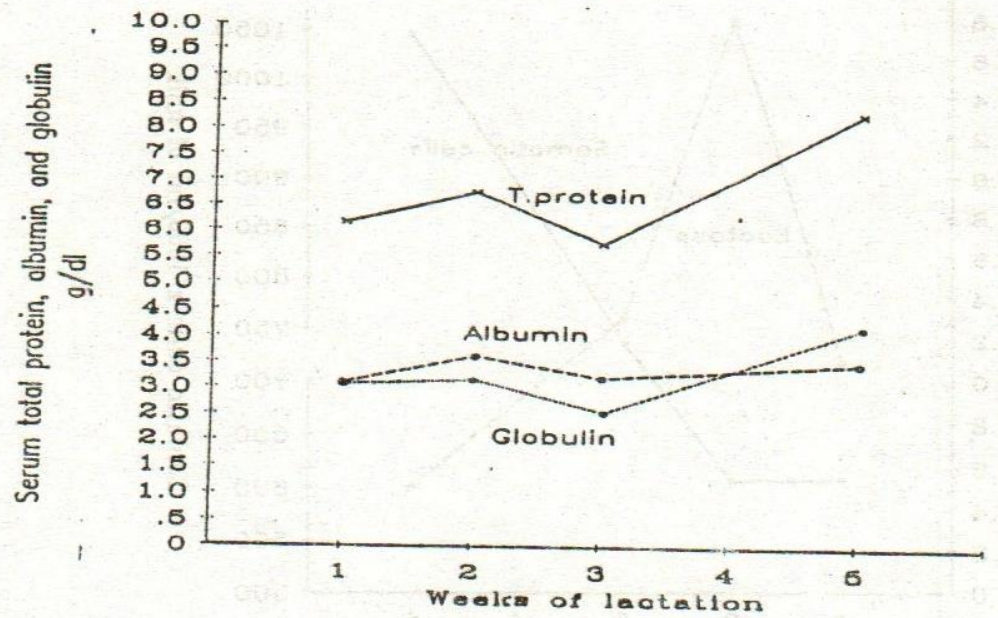

Assiut Vet. Med. J. Vol. 29, No. 58, 1993. 